УДК 339.923:061.1€С

BEATA BAZELI

Dr.Sc. (Economics),

Kujawy and Pomorze University in Bydgoszcz

st.Torunska, 55-57, s.Bydgoszcz, 85-023, Poland

PIOTR GUDZ

Dr.Sc. (Economics), Prof.

professor of department of right and administration of

Kujawy and Pomorze University in Bydgoszcz,

st.Torunska, 55-57, s.Bydgoszcz, 85-023, Poland

E-mail:pitgudz@gmail.com

MONIKA ADAMSKA

Graduate student

Kujawy and Pomorze University in Bydgoszcz

st.Torunska, 55-57, s.Bydgoszcz, 85-023, Poland

\title{
ZARZĄDZANIE PROJEKTAMI UNIJNYMI W POLSCE APOWIECIE PILSKIM
}

У статті проаналізовано програми Свропейського Союзу, які активно реалізуються в Польщі. Автори показують зиск і шкоду від програм Свропейського Союзу в регіоні Польському.

Wstęp. Polska przystąpiła do struktur Unii Europejskiej 1 maja 2004 r. Jednak z funduszy unijnych Polska korzystała już od 2000 r. Jako kraj przystępujący do Unii Europejskiej mogliśmy liczyć na bezzwrotną pomoc z tzw. Funduszy przedakcesyjnych. Są to specjalne środki przeznaczone dla krajów, które przygotowują się do przystąpienia do Unii Europejskiej. Mają one służyć wyrównaniu różnic gospodarczych pomiędzy krajami będącymi członkami wspólnoty, a tymi które do niej przystępują. Najwięcej środków z tych programów trafiło do samorządów lokalnych. Po przystąpieniu do struktur UE Polska uzyskała pierwsze środki na lata 2007-2013. W swojej pracy omówię sposób wykorzystania i mechanizmy służące wykorzystaniu przyznanego dofinansowania. Obecnie nasz kraj otrzymał nowe środki na lata 2014-2020, których wydatkowanie właśnie się rozpoczyna. Przykładowa inwestycja, którą omówię będzie pochodzić z powiatu pilskiego.

Główna część. Fundusze służące przygotowaniu państw przystępujących do struktur Unii Europejskiej. Celem ich przyznania było wyrównanie różnic w rozwoju społecznym i gospodarczym państw przystępujących do wspólnoty [1].W obecnym kształcie fundusze przedakcesyjne funkcjonują od $2000 \mathrm{r}$. Jako pierwsze skorzystały z nich państwa z Europy Środkowej i Wschodniej, w tym Polska. Wysokość środków przyznanych w ramach pomocy określana była na podstawie wskaźników ekonomicznych i statystycznych takich jak: obszar, gęstość zaludnienia. Ponadto brano pod uwagę również dotychczasowy stopień wykorzystania środków pomocowych [2]. Środki przyznane z funduszy mogły zostać wykorzystane za pomocą 3 instrumentów finansowych opracowanych przez Unię Europejską: ISPA (środowisko naturalne i transport), SAPARD (rolnictwo i rozwój obszarów wiejskich), PHARE (społeczeństwo i infrastruktura) [3].

Analiza tych programów pokazała następne. Program ISPA został utworzony w drodze rozporządzenia Rady UE nr 1267/99 z dn. 25 czerwca 1999 r. Celem głównym funduszu było wsparcie krajów kandydujących poprzez współfinansowanie dużych projektów inwestycyjnych w sektorze środowiska i transportu. Obejmowało w szczególności:

-W obszarze środowiska: wspieranie przedsięwzięć umożliwiających krajom dostosowanie się do wspólnotowego prawa ochrony środowiska oraz do celów Partnerstwa dla Członkostwa 
-W obszarze transportu: wspieranie przedsięwzięć umożliwiających krajom dostosowanie się do celów Partnerstwa dla Członkostwa, poprzez stworzenie połączeń sieci krajowej z siecią transeuropejską oraz ujednolicenie warunków wykorzystania tych sieci.

Wszystkie projekty realizowane w ramach funduszu ISPA musiały być efektywne ekonomicznie, tzn. przynosić korzyści netto dla społeczeństwa. Koszt przedsięwzięć dopuszczonych do realizacji musiał wynosić co najmniej $5 \mathrm{mln}$ euro. Dofinansowanie ze środków funduszu nie mogło przekroczyć $75 \%$ kosztów inwestycji, jednak w drodze wyjątku dopuszczone były również dofinansowania w wysokości 85\% kosztów [4, s. 680]. Srodków z ISPA nie można było łączyć z innymi funduszami przedakcesyjnymi. Podział tych środków następował na podstawie następujących kryteriów: liczba ludności, wielkość PKB na głowę mieszkańca liczonego według parytetu siły nabywczej oraz powierzchnia kraju. Polska otrzymała wsparcie na realizację w sumie 69 projektów inwestycyjnych. Były to inwestycje w infrastrukturę kolejową i drogową w ramach krajowych sieci transportowych oraz połączeń z sieciami transeuropejskimi. Natomiast $\mathrm{w}$ odniesieniu do ochrony środowiska zrealizowano projekty służące spełnieniu wymogów unijnych dotyczących dostaw wody pitnej, odprowadzania i oczyszczania ścieków, utylizacji odpadów i ochrony atmosfery.

Głównym celem Programu SAPARD było wsparcie procesów restrukturyzacji obszarów wiejskich. Ponadto realizacja programu miała przygotować odpowiednie instytucje oraz potencjalnych beneficjentów do korzystania z instrumentów Wspólnej Polityki Rolnej, w ramach której Polska funkcjonuje od akcesji w 2004 r. Podstawę prawną dla Programu stanowiły akty prawne UE: Rozporządzenie Rady (WE) nr 1268/99 z dnia 21 czerwca 1999 r. oraz Rozporządzenie KE (WE) nr 2222/2000 z dnia 7 czerwca 2000 r., które regulowały podział środków przyznanych Polsce na lata 2000-2006. Budżet programu wyniósł 1,084 mld euro. Środki Unii Europejskiej wyniosły 708,2 mln euro, zaś dofinansowanie krajowe 235,8 mln euro. $140 \mathrm{mln}$ euro przesunięto za zgodą Komisji Europejskiej z budżetu Planu Rozwoju Obszarów Wiejskich (PROW). Program SAPARD został uruchomiony na początku lipca 2002 r. i objął następujące działania:

- Działanie 1. Poprawa przetwórstwa i marketingu artykułów rolnych i rybnych

- Działanie 2. Inwestycje w gospodarstwach rolnych

- Działanie 3. Rozwój i poprawa infrastruktury obszarów wiejskich

- Działanie 4. Różnicowanie działalności gospodarczej na obszarach wiejskich (Działanie uruchomione 3 grudnia $2003 \mathrm{r}$.)

- Działanie 6. Szkolenia zawodowe

- Działanie 7. Pomoc techniczna [5, s. 5].

Po akcesji ciężar pomocy finansowej na przedsięwzięcia m.in. w zakresie poprawy przetwórstwa i marketingu artykułów rolnych, różnicowania działalności gospodarczej na obszarach wiejskich oraz inwestycje w gospodarstwach rolnych został przeniesiony m.in. na Sektorowy Program Operacyjny Restrukturyzacja i modernizacja sektora żywnościowego oraz rozwój obszarów wiejskich.

Głównym celem programu PHARE było zmniejszanie opóźnień i nierównomierności rozwoju regionów poprzez promowanie aktywności gospodarczej, rozwiązywanie problemów społecznych związanych z rynkiem pracy, restrukturyzację oraz rozwój infrastruktury. Dodatkowo realizacja programu miała za zadanie przygotować administrację publiczną na wszystkich szczeblach do programowania i wdrażania projektów realizowanych przy wsparciu Funduszy Strukturalnych dostępnych dla Polski po 1. maja 2004 r.

Program PHARE SSG składa się z trzech głównych części (komponentów):

- wsparcia rozwoju infrastruktury (INFRA),

- wsparcia małych i średnich przedsiębiorstw (MSP) - Celem jest pobudzenie aktywności gospodarczej sektora małych i średnich przedsiębiorstw zapewniającej wzrost zatrudnienia w tym sektorze oraz wzrost jego konkurencyjności i zdolności do funkcjonowania na Jednolitym Rynku Europejskim.

- wsparcia rozwoju zasobów ludzkich (RZL) - Mają one na celu wsparcie czterech filarów Europejskiej Strategii Zatrudnienia: wzrost możliwości zatrudnienia, rozwój przedsiębiorczości, umiejętność dostosowania się i równość szans mężczyzn i kobiet na rynku pracy.

Wysokość grantu UE wynosiła maksymalnie 75\% wartości poszczególnych projektów. Natomiast współfinansowanie krajowe zapewniane było ze środków beneficjentów - jednostek samorządu terytorialnego oraz ze środków budżetu państwa. Instytucją Wdrażającą dla projektów przeznaczonych dla małych i średnich przedsiębiorstw oraz na rozwój zasobów ludzkich była Polska Agencja Rozwoju Przedsiębiorczości [2, s. 53]. 
W latach 2010-2015 największym beneficjentem środków unijnych wśród nowych państw członkowskich była Polska. Na finansowanie planowanych inwestycji przeznaczono 85 miliardów euro [6, s. 15]. Komisja Europejska w lipcu 2005 r. określiła Strategiczne Wytyczne Wspólnoty na lata 2007-2013, w których znalazły się trzy priorytety polityki spójności:

1. Poprawa atrakcyjności państw członkowskich poprzez poprawę dostępności, zapewnienie odpowiedniej jakości oraz poziomu usług przy jednoczesnym zachowaniu potencjału środowiskowego.

2. Działanie na rzecz przedsiębiorczości, innowacji i wzrostu gospodarki poprzez zwiększenie zdolności innowacji i badań naukowych, w tym także nowych technologii informacyjnych i komunikacyjnych.

3. Tworzenie lepszych miejsc pracy poprzez poprawę warunków doszkalających pracownika oraz zwiększenie inwestycji w kapitał ludzki [7].

Padła również propozycja, aby przy realizacji projektów zakładać trzy nowe cele: konwergencję, podniesienie konkurencyjności regionów i zatrudnienia oraz europejską współpracę terytorialną. Konwergencja to spójność, co w praktyce oznacza wspieranie przez Unię rozwoju infrastruktury i potencjału gospodarczego najbiedniejszych regionów. Podniesienie konkurencyjności polega na wspieraniu innowacyjności i badań naukowych, a także na doszkalaniu i podnoszeniu kwalifikacji zawodowych. Natomiast Europejska Współpraca Terytorialna ma za zadanie promocję regionów i realizowanie projektów międzynarodowych we wszystkich państwach członkowskich UE. Można więc wywnioskować, że polityka spójności to ogólne wspieranie wzrostu gospodarczego, społecznego i przestrzennego państw członkowskich. Specjalnie stworzone do tego celu fundusze umożliwiały finansowanie polityki spójności. Były nimi: Europejski Fundusz Rozwoju Regionalnego, Europejski Fundusz Społeczny, a także Fundusz Spójności. Największym z nich jest Europejski Fundusz Rozwoju Regionalnego. Jego cel to wspieranie regionów, mając na uwadze przede wszystkim wyrównywanie różnic pomiędzy bogatymi i biednymi regionami.

W ramach tego funduszu finansowaniem objęte były programy stworzone do wspierania rozwoju regionów. Europejski Fundusz Społeczny stworzono po to, aby umożliwić zatrudnienie na terenie całej Unii Europejskiej, ułatwić dostępność miejsc pracy oraz poprawić jej warunki. Osiągnięcie tego miały umożliwić liczne szkolenia i warsztaty finansowane ze środków Europejskiego Funduszu Społecznego. Fundusz Spójności wspierał dwa sektory: transport i środowisko. Środki przyznawane były m. in. na finansowanie dużych inwestycji związanych z ochroną środowiska. Głównymi beneficjentami były samorządy terytorialne, związki gmin i inne podmioty publiczne [8]. Dla sektorów rolnictwa i rybołówstwa stworzono 2 osobne instrumenty działające poza Funduszem Spójności: Europejski Fundusz Rolny Obszarów Wiejskich i Europejski Fundusz Rybacki [9, s. 21]. Na Narodową Strategię Spójności w latach 2007-2013 przeznaczono łącznie 74,6 mld euro. Środki wspólnotowe stanowiły 59,5 mld euro, środki krajowe 9,8 mld euro, natomiast środki podmiotów prywatnych - 5,3 mld euro. Na Europejski Fundusz Rozwoju Regionalnego przeznaczono 52\% środków wspólnotowych, na Europejski Fundusz Społeczny 15\%, natomiast pozostałe 33\% na Fundusz Spójności [10, s. 25].

Na potrzeby realizacji Narodowej Strategii Spójności opracowano 7 programów operacyjnych. Określały one typy przedsięwzięć, na które przewidziano udzielenie wsparcia finansowego, a także podmioty, które mogły ubiegać się o dotacje. Podział środków na poszczególne programy operacyjne przedstawiał się następująco:

Podział środków na poszczególne Programy Operacyjne [8]

\begin{tabular}{|l|l|l|}
\hline Program & $\begin{array}{l}\text { Alokacja } \\
\text { (w mld euro) }\end{array}$ & $\begin{array}{l}\text { Udział \% } \\
\text { w alokacji }\end{array}$ \\
\hline Program Infrastruktura i Srodowisko & 28,3 & 41,8 \\
\hline Program Kapitał Ludzki & 10 & 14,7 \\
\hline Program Innowacyjna Gospodarka & 8,7 & 12,7 \\
\hline Program Rozwój Polski Wschodniej & 2,4 & 3,5 \\
\hline Program Pomoc Techniczna & 0,5 & 0,8 \\
\hline Program Europejskiej Współpracy terytorialnej & 0,7 & 1,1 \\
\hline 16 Programów Regionalnych & 17,3 & 25,4 \\
\hline Razem & 67,9 & 100 \\
\hline
\end{tabular}

Tabela 1 
Na północy województwa Wielkopolskiego położony jest powiat pilski uznawany w latach 1975-1998 za województwo Pilskie. Obszar obecnego powiatu określono w 1999 r. po przekształceniu wspomnianego województwa. Zajmuje on powierzchnię $1268 \mathrm{~km} 2$, a także charakteryzuje się najwyższym wskaźnikiem urbanizacji, który wynosi $65,1 \%$. W skład powiatu wchodzą następujące gminy: Piła, Łobżenica, Ujście, Wyrzysk, Wysoka, Białośliwie, Kaczory, Miasteczko Krajeńskie i Szydłowo. Swoje korzystne położenie zawdzięcza dwóm makroregionom: Pojezierzu Południowo-Pomorskiemu oraz Pradolinie ToruńskoEberswaldzkiej. Krajobraz powiatu jest w większości rolniczy. Wśród gospodarstw dominują indywidualne, występują jednak niewielkie rolnicze spółdzielnie produkcyjne. Razem tereny rolnicze zajmują obszar ok. 75800 ha. W produkcji dominuje uprawa zbóż, hodowla zwierząt i mleczarstwo. W okolicach Noteci przeważa uprawa warzyw, natomiast gmina Białośliwie jest jednym $\mathrm{z}$ najważniejszych ośrodków sadowniczych w Wielkopolsce. Znaczny obszar zajmują również lasy, co przyczynia się do rozwoju leśnictwa.

Dzięki temu pozyskuje się tarcicę- ważny surowiec wykorzystywany w meblarstwie i przemyśle papierniczym. Przedmiot eksportu stanowi również runo leśne. W Kalinie znajduje się siedziba Regionalnej Dyrekcji Lasów Państwowych, która zarządza lasami o łącznej powierzchni ok. $346 \mathrm{~km}^{2}$, które zajmują teren 4 województw i 14 powiatów. Tereny leśne powiatu pilskiego należą głównie do Nadleśnictwa Zdrojowa Góra i Kaczory. Liczne walory naturalne powiatu stanowią solidną podstawę jego gospodarki. Według ostatnich danych Działalność gospodarczą na terenie powiatu pilskiego na podstawie wpisu do rejestru prowadzi 11395 podmiotów gospodarczych w sektorze prywatnym oraz 421 podmiotów w sektorze publicznym. W sektorze prywatnym najwięcej podmiotów gospodarczych znajduje się w Gminie Piła, a następnie w Gminie Wyrzysk, Ujście oraz Szydłowo. Oznacza to, że władze w skuteczny sposób wspierają przedsiębiorczość mieszkańców. Powiat jest atrakcyjnym ośrodkiem dla inwestorów również zagranicznych, którzy chętnie lokują w nim swój kapitał. Funkcjonuje tu ok. 30000 podmiotów gospodarczych. Dominują branże elektryczna, elektroniczna i poligraficzna. Administracyjną stolicą powiatu pilskiego jest miasto Piła. Otoczone lasami i jeziorami miasto stanowi największy ośrodek kulturalno-przemysłowy.

Instytut Badań nad Gospodarką Rynkową przyznał jej tytuł lidera pod względem atrakcyjności inwestycyjnej. Istnieje tu specjalna, wydzielona strefa ekonomiczna, w której inwestorzy mogą uzyskać do 60\% zwrotu zainwestowanego kapitału. W minionej perspektywie finansowej powiat pilski realizował projekty dofinansowane z funduszy europejskich w kilku sektorach gospodarczych. Należały do nich projekty miękkie: wsparcie szkolnictwa - projekty realizowane w szkołach, projekty aktywizacyjne dla osób bezrobotnych, jak również projekty twarde - inwestycje drogowe, modernizacje linii kolejowych.

Jedną z największych, jak również mających istotny wpływ na rozwój regionu inwestycji była budowa Południowej obwodnicy powiatu pilskiego. Projekt został zrealizowany $\mathbf{z}$ udziałem środków unijnych w ramachWielkopolskiego Regionalnego Programu Operacyjnego na lata 2010-2015. Projekt przewidywał remont siedmiu fragmentów dróg powiatowych przechodzących przez powiat pilski. Zrealizowana inwestycja w zdecydowany sposób poprawiła sytuację na drodze krajowej nr 10, która cechuje się dużym natężeniem ruchu. Ze względu na stan techniczny przebudowa dróg stała się najistotniejszą inwestycją dla władz samorządowych powiatu, ponieważ taka sytuacja stwarzała zagrożenie dla bezpieczeństwa użytkowników dróg, jak również środowiska naturalnego. Trasa obwodnicy zaczyna się w Ujściu na skrzyżowaniu z drogą krajową nr 11 i kończy w miejscowości Ruda na skrzyżowaniu z drogą krajową nr 10. Najbardziej niebezpiecznym odcinkiem jest droga pomiędzy Grabównem i Wyrzyskiem, dla której obwodnica dała możliwość rozładowania natężenia ruchu. Łączna długość przebudowywanych dróg wyniosła $53,25 \mathrm{~km}$.

Fundusze unijne na lata 2016-2020 Polska otrzymała kolejną transzę środków z funduszy unijnych. Zostaną one zainwestowane w zwiększenie konkurencyjności polskiej gospodarki, poprawę spójności społecznej i terytorialnej kraju, a także w podnoszenie sprawności i efektywności administracji. Najważniejszym celem programów będzie poprawa poziomu życia mieszkańców dzięki wzrostowi gospodarczemu i wzrostowi zatrudnienia. Obok bezzwrotnych dotacji UE udostępnia także tzw. instrumenty zwrotne, czyli pożyczki i kredyty. Korzystać z nich mogą zarówno przedsiębiorcy, jak i samorządy. Perspektywa na lata 2014-2020 będzie wdrażana w Polsce poprzez 6 krajowych programów operacyjnych zarządzanych przez Ministerstwo Rozwoju oraz 16 programów regionalnych zarządzanych przez Urzędy Marszałkowskie. Rodzaje programów operacyjnych: Program Infrastruktura i Środowisko, Program Inteligentny Rozwój, Program Wiedza Edukacja Rozwój, Program Polska Cyfrowa, Program Polska Wschodnia, Program Pomoc Techniczna [8]. 
Obecnie w powiecie pilskim realizację rozpoczęły projekty miękkie: głównie szkolenie i aktywizacja osób bezrobotnych. Są one realizowane zarówno przez instytucje (Powiatowe Urzędy Pracy), jak również przez prywatne firmy. Efekty tych działań będą widocznie pod koniec obecnej perspektywy finansowej.

Zakończenie. Polska jest w UE od 15 lat i efekty przystąpienia do wspólnoty widać na każdym kroku. Wyraźny rozwój infrastruktury drogowej nie tylko w powiecie pilskim, ale także w całym kraju, programy wspierające przedsiębiorstwa i naukę. To wszystko sprawia, że coraz bardziej optymistycznie możemy patrzeć w przyszłość. Polska staje się coraz mocniejszym państwem na arenie międzynarodowej i coraz mocniejszym partnerem w wielu organizacjach międzynarodowych. Zdecydowany wpływ na to ma tempo, w jakim nasz kraj się rozwija. Weszliśmy w nową perspektywę budżetową i otrzymaliśmy największe wsparcie spośród członków wspólnoty. Stanowi to kolejną szansę na poprawę sytuacji gospodarczej naszego państwa, a co za tym idzie, także jednostek samorządowych, których przykładem jest powiat pilski. Programy operacyjne stworzone na potrzeby realizacji inwestycji finansowanych ze środków unijnych pomagają w efektywny sposób je wykorzystać. Ich struktura oraz sposób funkcjonowania są zgodne ze wszelkimi normami unijnymi i krajowymi.

\section{ЛITЕРАТУРА}

1. Fundusze i programy pomocowe UE [Funds and eleemosynary programs of European Union] (2006). - Warszawa: UKIE [in Poland].

2. Hibner, M. Janus, Pastusiak, R. Programy pomocowe w Polsce [The eleemosynary programs in Poland] (2004). - Warszawa: CeDeWu [in Poland].

3. Fundusze przedakcesyjne. Retrieved from www.bcgconsulting.pl/fundusze [in Poland].

4. Doliwa-Klepacki, Z. Integracja Europejska [European Integration] (2005). - Białystok [in Poland].

5. Program SAPARD, Ministerstwo Rolnictwa i Rozwoju Wsi [Ministry of Agriculture and Development of Village] (2000). - Warszawa [in Poland].

6. Cieślak, R. Fundusze unijne 2007-2015 Wsi [Funds of Villages of European Union 2007-2015] (2016). - Wrocław [in Poland].

7. Portal wiedzy o funduszach europejskich [Portal of knowledge about the European funds] (2017). Retrieved from www.europa.eu/regional_policy/sources/docoffic [in Poland].

8. Portal Funduszy Europejskich [Portal of the European funds] (2017). Retrieved from www.funduszeeuropejskie.gov.pl/WstepDoFunduszyEuropejskich/Strony/ [in Poland].

9. Szymańska, A. Fundusze UE 2010-2015 dla mikro, małych i średnich firm [Funds of the European 2010-2015 for small and middle firms] (2016). - Warszawa [in Poland].

10.Śliwa, J. Fundusze unijne bez tajemnic [Funds of European Union without secrets] (2008). Warszawa: UW [in Poland].

11.Powiat Pilski. Nowe programy PFRON [District of Pilski. New programs PFRON] (2017) Retrieved from www.powiat.pila.pl/starostwo; powiat-pilski

\section{REFERENCES}

1. Fundusze i programy pomocowe UE, UKIE (2006). Warszawa.

2. Hibner, M. Janus, Pastusiak, R. (2004). Programy pomocowe w Polsce, CeDeWu, Warszawa.

3. Fundusze przedakcesyjne.www.bcgconsulting.pl/fundusze, (Data dostępu: 13.01.2017)

4. Doliwa-Klepacki, Z. (2005). Integracja Europejska, Białystok.

5. Program SAPARD, Ministerstwo Rolnictwa i Rozwoju Wsi (2000). Warszawa.

6. Cieślak R., Fundusze unijne 2007-2015 (2016). Poradnik przedsiębiorcy, Wrocław.

7. Portal wiedzy o funduszach europejskich www.europa.eu/regional_policy/sources/docoffic, (Data dostępu: 13.01.2017)

8. Portal Funduszy Europejskich. www.funduszeeuropejskie.gov.pl/WstepDoFunduszyEuropejskich/Stro ny/, (Data dostępu: 13.01.2017)

9. Szymańska, A., Fundusze UE 2010-2015 dla mikro, małych i średnich firm (2016). Warszawa.

10.Śliwa, J., Fundusze unijne bez tajemnic. Podręcznik dla studentów (2008). Warszawa: Wyd. Nauk. Wydziału Zarządzania UW.

11.Powiat Pilski. Nowe programy PFRON. www.powiat.pila.pl/starostwo; powiat-pilski, (Data dostępu: 13.01.2017). 